\title{
Pencucian Uang dan Kejahatan Terorganisir
}

\author{
M. Arief Amrullah
}

\begin{abstract}
One of the major activities of transnational criminal organizations is profit taking. Although a considerable portion of this come from drug trafficking, other forms of transnational crime may account for a significantly high percentage of all the illegal proceeds that enter the global financial system. The problem for these groups, however, is that the money derived from illicit proceeds has somehow to be made legitimate through the laundering process.
\end{abstract}

\section{Pendahuluan}

Money laundering atau pencucian uang, merupakan salah satu jenis kejahatan yang mendunia dan merupakan bagian dari kejahatan terorganisir. Timbulnya jenis kejahatan tersebut, tidak terlepas dari perkembangan masyarakat itu sendiri. Oleh karena itu, wajar jika ada suatu ungkapan: kejahatan itu tua dalam usia, tapi muda dalam berita. Artinya, sejak dulu hingga kini orang selalu membicarakan mengenai kejahatan, mulai dari yang sederhana (kejahatan biasa) sampai kepada kejahatan-kejahatan yang sulit pembuktiannya, atau mulai dari kejahatan dilakukan secara terang-terangan (kasar) sampai kepada kejahatan yang dilakukan secara diam-diam atau sembunyi-sembunyi.
Sehubungan itu, BenedictS. Alper ${ }^{2}$ menulis bahwa kejahatan sebenarnya merupakan problem sosial yang paling tua, dan sehubungan dengan masalah ini sudah tercatat lebih dari 80 kali konferensi internasional yang dimulai tahun 1825 hingga tahun 1970 yang membahas upaya-upaya untuk mengatasi persoalan kejahatan. Tidak berhenti sampai di situ, ${ }^{2}$ dalam konferensikonferensi PBB selanjutnya yang membahas seputar The Crime Prevention and the Treatment of Offenders, berturut-turut pada tahun 1975 diselenggarakan di Geneva, menyetujui sebuah Deklarasi tentang the Protection of All Persons from Torture and laid the basis for a code of ethics for law enforcement officials.

'Benedict S. Alper, "Changing Concept of Crime and Criminal Policy", Dalam Resource Material Series No. 6, UNAPEI, Fuchu, Tokyo, Japan, Oktober 1973, hlm. 85. Crime is the oldest social problem on which there has been international concem and action, beginning in 1825, and recorded in more than 80 intemational conferences held on this subject between then and 1970.

${ }^{2}$ http://www.odccp.org/crime cicp previous congresses.html, diakses 22 Januari 2003. 
Tahun 1980 diselenggarakan di Caracas membicarakan crime trends and prevention strategies, juvenile justice, crime and the abuse of power and the treatment of prisoners. Tahun 1985 diselenggarakan di Milan, menyepakati the Milan Plan of Action calling on the international community to address socio-economic factors relevant to the commission of crime. Tahun 1990 diselenggarakan di Havana, membicarakan isu-isu tentang theft of archaeological treasures, the dumping of hazardous wastes in oceans, drug trafficking and the link between drug abuse and the rise of AIDS among prisoners. Tahun 1995 diselenggarakan di Cairo, membicarakan tindakan-tindakan to combat transnational crime, terrorism and violence against women; conducted an unprecedented debate on corruption of public officials, led by a panel of expert. Terakhir, diselenggarakan di Vienna dari tanggal 10 sampai dengan 17 April 2000, dengan tema Crime and Justice, meeting the Challenges of the $21^{s t}$ century. Bahkan dalam Kongres PBB ke-5 tentang the Prevention of Crime and the Treatment of Offenders yang diselenggarakan di Jenewa dari tanggal 1 hingga 12 September 1975 telah memfokuskan pembicaraan mengenai crime as business at the national and transnational levels yang meliputi organized crime, white-collar crime dan corruption. Crime as business itu diakui sebagai ancaman yang serius terhadap masyarakat dan ekonomi nasional dibandingkan dengan bentuk kejahatan tradisional. Dalam kongress berikutnya, yaitu Kongres PBB ke- 6 tentang the Prevention of Crime and the Treatment of Offenders yang diselenggarakan di Caracas tanggal 25 Agustus hingga 5 September 1980, telah dibicarakan mengenai crime and the abuse of power. Lebih lanjut dinyatakan, bahwa Konsep tentang abuse of power itu sendiri menempati beberapa bidang, baik bidang politik, ekonomi maupun sosial. Kesemua bidang itu, saling terkait dan keterjalinan satu sama lainnya. ${ }^{3}$

Kejahatan, merupakan sebuah istilah yang sudah lazim dan populer di kalangan masyarakat Indonesia atau crime bagi orang Inggris menyebutnya. Tapi, jika ditanyakan: apa sebenarnya yang dimaksud dengan kejahatan? Orang mulai berpikir, dan atau bahkan balik bertanya. Menurut Hoefnagels ${ }^{4}$ apa yang dimaksud dengan kejahatan, merupakan suatu pengertian yang relatif. Banyak pengertian yang digunakan dalam ilmu-ilmu sosial yang berasal dari bahasa sehari-hari (common parlance), tetapi mereka jarang sama dalam mengartikannya. Mengapa demikian?, karena bahasa sehari-hari tersebut tidak memberikan gambaran yang jelas dari kejahatan itu sendiri, tetapi hanya merupakan suatu ekspresi dalam melihat perbuatan tertentu. Dalam kaitan ini, Sahetapy menulis ${ }^{5}$ bahwa pengertian atau makna kejahatan bisa saja tumpang tindih dengan pengertian kejahatan secara yuridis, atau bisa juga serupa

${ }^{3}$ United Nations, Economic and Social Council, "Appropriate Modalities and Guidelines for the Prevention and Control of Organized Transnational Crime at the Regional and Intemationai Levels", World Ministerial Conference on Organized Transnational Crime, Naples, 21-23 November 1994, hlm. 3.

${ }^{4} \mathrm{G}$. Peter Hoefnagels, The Other Side of Criminology, An Inversion of the Concept of Crime, 1972, h/m. 72.

5 J.E. Sahetapy, Teori Kriminologi Suatu Pengantar, (Bandung: Citra Aditya Bakti, 1992), him. 67. 
dengan makna kejahatan secara kriminologis. Namun, yang jelas menurut Sahetapy makna dan ruang lingkup kejahatan secara yuridis tidak sama dan tidak serupa dengan makna serta ruang lingkup makna kejahatan secara kriminologis.

Pandangan di atas, sesuai dengan pendapat yang dikemukakan oleh Sudarto ${ }^{6}$ bahwa ada perbedaan pendapat dalam melihat kejahatan sebagai gejala masyarakat. Dalam hal ini Sudarto memberikan contoh, misalnya:

orang tidak akan berbeda pendapat, bahwa penodongan itu suatu kejahatan, akan tetapi mengenai permintaan "uang hangus" oleh seorang pegawai bank yang terpaksa harus dituruti oleh seorang peminjam uang, yang disinyalir oleh Presiden Suharto sebagai hal yang harus dihapus, mungkin ada orang yang berpendapat, bahwwa itu sesuatu yang sudah sewajamya!

Demikian juga halnya dengan pencucian uang. Menurut para pelakunya bahwa itu wajar dan tidak ada yang menyimpang, karena semuanya dilakukan sesuai dengan prosedur yang ditetapkan oleh bank (sebagai salah satu lembaga keuangan), di samping juga hanya merupakan hubungan keperdataan antara nasabah (penyimpan dana) dengan pihak bank. Tapi, menurut pandangan para pemerhati, perbuatan menyimpan uang di bank itu tidak lagi dapat dilihat atau berlindung dibalik hubungan keperdataan sebagaimana lazimnya dalam dunia perbankan, karena apa yang dilakukan oleh si penyimpan dana adalah sebagai upaya untuk mengaburkan asal-usul uang yang disimpan, sehingga perbuatan seperti itu merupakan kejahatan yang perlu ditindak dan diberantas.

Berdasarkan uraian di atas, timbul pertanyaan: apakah dalam urusan menyimpan uang hasil kejahatan di bank misalnya, masih disepakati sebagai masalah keperdataan dan bukan merupakan kejahatan? Jawaban untuk pertanyaan ini, barangkali dapat dikembalikan pada tulisan Sahetapy sebagaimanà telah dikemukakan di atas tadi, yang pada akhimya bergantung dari sudut mana orang hendak melihatnya, apakah dari sudut yuridis ataukah dari sudut kriminologis. Apabila hendak dilihat dari sudut yuridis, maka pertanyaannya, apakah kejahatan berupa pencucian uang tersebut merupakan kejahatan menurut hukum pidana positif. Jika demikian halnya, tentu tidak ada pilihan lain, kecuali membuka undangundang. Sebaliknya, apabila hendak melihat dari sudut kriminologis, jawabannya pun tergantung pada siapa yang melihatnya, dan itu juga tergantung dari subyektifitas dan yang terancam kepentingannya.

Sebagai kejahatan yang mendunia, di mana kejahatan pencucian uang telah masuk dalam kelompok kegiatan organisasiorganisasi kejahatan transnasional (Activities of Transnational Criminal Organizations) yang meliputi the drug trafficking industry, smuggling of illegal migrants, arms trafficking, trafficking in nuclear material, transnational criminal organizations and terrorism, trafficking in women and children, trafficking in body parts, theft and smuggling of vehicles, money laundering, dan jenis-jenis kegiatan lainnya, ${ }^{7}$ sangat

'Sudarto, Hukum dan Hukum Pidana (Bandung: Alumni, 1983), hlm. 161. 
memprihatinkan masyarakat internasional.

Adanya keprihatinan tersebut tentunya sangat beralasan, yaitu apabila dikaitkan dengan ancaman atau akibat yang ditimbulkannya sangat begitu dahsyat (insidious), dan dapat menembus ke berbagai segi atau bidang, baik terhadap keamanan dan stabilitas nasional maupun internasional, dan merupakan ancaman utama (frontal attack) terhadap kekuasaan politik dan legislatif, dan ancaman bagi kewibawaan negara. Di samping itu, juga mengganggu dan mengacaukan lembaga-lembaga sosial dan ekonomi, menyebabkan longgamya penegakan proses demokrasi, serta merusak pembangunan dan menyelewengkan hasil-hasil yang sudah dicapai. Mengorbankan penduduk, mempergunakan kesempatan atas kelengahan manusia sebagai sasarannya. Memperangkap dan bahkan memperbudak golongan-golongan masyarakat, khususnya wanita dan anak-anak dalam melakukan pekerjaan illegal di berbagai bidang dan keterkaitan satu sama lain, terutama sekali dalam prostitusi. ${ }^{8}$

Kaitannya dengan kejahatan money laundering (pencucian uang), di mana tujuan utama dilakukannya jenis kejahatan ini adalah untuk menghasilkan keuntungan, baik bagi individu maupun kelompok yang melakukan kejahatan tersebut. Menurut suatu perkiraan baru-baru ini, hasil dari kegiatan money laundering seluruh dunia dalam perhitungan secara kasar berjumlah satu triliun dollar setiap tahun. Dana-dana gelap ini akan digunakan oleh pelaku untuk membiayai kegiatan kejahatan selanjutnya. ${ }^{9}$ Selain itu, Dana Moneter Internasional (IMF) menyatakan bahwa jumlah keseluruhan money laundering di dunia diperkirakan antara dua dan lima persen produk domestik bruto dunia. Apabila menggunakan statistik tahun 1996, prosentase ini menunjukkan bahwa money laundering berkisar antara 590 milyar US Dollar dan 1,5 triliun US Dollar. Angka terendah adalah kirakira setara dengan nilai keseluruhan produk ekonomi Spanyol..$^{10}$

Sehubungan dengan itu, maka patut dipertanyakan: apakah yang dimaksud dengan money laundering? Mengenai hal ini, terdapat bermacam-macam pengertian namun kesemuanya itu tetap dalam satu tujuan untuk menyatakan bahwa money laundering merupakan salah satu jenis kejahatan yang potensial dalam mengancam berbagai kepentingan baik dalam skala nasional maupun internasional. Money laundering merupakan sebuah istilah yang pertama kali

'United Nation, Economic and Social Council, "Problem and Dangers Posed by Organized Transnational Crime in the Various Regions of the World", World Ministerial Conference on Organizied Transnational Crime, Naples, 21-23 November 1994, him. 17-22.

B/bid., hlm. 24.

${ }^{9}$ Ambassador Wendy Chamberlin, Principal Deputy Assistant Scretary, Bureau for International Narcotics and Law Enforcement Affairs, U.S. Department of State, in Economic Perspectives, The Fight Against Money Laundering.

${ }^{10}$ Financial Action Task Force on Money Laundering, Basic Facts about Money Laundering, http:/l uww1.oecd.org/fatf/MLaundering en.htm, diakses 19/06/2002, hlm. 2. 
digunakan di Amerika Serikat untuk menunjuk kepada pencucian hak milik Mafia, yaitu hasil usaha yang diperoleh secara gelap dicampurkan dengan maksud menjadikan seluruh hasil tersebut seolah diperoleh dari sumber yang sah. Singkatnya, istilah money laundering pertama kali digunakan dalam konteks hukum dalam sebuah kasus di Amerika Serikat tahun 1982 menyangkut denda terhadap pencucian uang hasil penjualan kokain Colombia. Dalam perkembangannya, proses yang dilakukan lebih kompleks lagi, dan sering menggunakan cara mutakhir sedemikian rupa sehingga seolah benar secara alami. Dengan cara demikian, membuat suatu kejelasan pembenaran untuk pengawasan atau kepemilikan uang yang dicuci."

Financial Action Task Force on Money Laundering (FATF) merumuskan, ${ }^{12}$ money laundering adalah proses menyembunyikan atau menyamarkan asal-asul hasil kejahatan. Proses tersebut untuk kepentingan penghilangan jejak, sehingga memungkinkan pelakunya menikmati keuntungan-keuntungan itu dengan tanpa mengungkap sumber perolehan tersebut. Penjualan senjata secara ilegal, penyelundupan, dan kegiatan kejahatan terorganisir, termasuk sebagai contoh perdagangan obat dan prostitusi, dapat menghasilkan jumlah uang yang banyak. Penggelapan, perdagangan orang dalam (insider trading), penyuapan dan bentuk penyalahgunaan komputer dapat juga menghasilkan keuntungan yang besar dan menimbulkan dorongan untuk menghalalkan (legitimise) hasil yang diperoleh melalui money laundering.

Pada mulanya kejahatan pencucian uang selalu dikaitkan dengan perdagangan narkotika atau psikotropika, tapi dalam perkembangannya diperluas hingga meliputi pula uang haram dari kejahatan-kejahatan terorganisir yang lain, ${ }^{13}$ dan sehubungan dengan telah berlakunya Undang-undang tentang Tindak Pidana Pencucian Uang, secara limitatif disebutkan 15 tindak pidana yang dapat dikategorikan sebagai kejahatan menurut undang-undang ini.

\section{Kaitan Pencucian Uang dengan Kejahatan Terorganisir}

Money Laundering yang merupakan kejahatan ekonomi, pada dasamya termasuk salah satu kejahatan terhadap pembangunan dan kejahatan terhadap kesejahteraan sosial yang menjadi pusat perhatian dan keprihatinan internal nasional dan eksternal internasional. Perhatian dan keprihatinan dunia intemasional

"United Nations Economic and Social Council, "Strengthening Existing International Cooperation in Crime Prevention and Criminal Justice, Including Technical Cooperation in Developing Countries, with Special Emphasis on Combating Organized Crime", Commission on Crime Prevention and Criminal Justice, First session, Vienna, 21-30 April 1992.

${ }^{12}$ Financial Action Task Force on Money Laundering, Basic Facts about Money Laundering, http:ll www1.oecd.org/fatf/MLaundering en.htm, diakses 19/06/2002, hal. 1 .

${ }^{13}$ Muladi, "Kemungkinan Kriminalisasi Money Laundering di Indonesia", Penataran Nasional Hukum Pidana dan Kriminologi, Hotel Siranda, Semarang, 3-15 Desember 1995, hal. 5. 
terhadap kejahatan pencucian uang itu tentunya sangat beralasan, karena ruang lingkup dan dimensinya begitu luas, sehingga kegiatannya mengandung ciri-ciri sebagai organized crime, white-collar crime, corporate crime, dan transnational crime. Bahkan dengan kemajuan teknologi dapat menjadi salah bentuk dari cyber crime. Mengingat karakteristik yang demikian, maka didirikannya Financial Action Task Force on Money Laundering (FATF) oleh negara-negara yang tergabung dalam kelompok G-7 di Paris tahun 1989 yang terdiri dari Kanada, Perancis, Jerman, Italia, Jepang, Inggris, dan Amerika Serikat, merupakan sebuah badan antar pemerintahan yang bertujuan untuk membangun kerjasama internasional dalam menghadapi jenis kejahatan ini. Salah satu tugas dari FATF tersebut adalah membuat rekomendasi-rekomendasi yang dapat membantu pemerintahan negara-negara to implement effective anti-money laundering programmes. Kebutuhan ini untuk mengkaver seluruh aspek-aspek yang relevan dengan upaya memerangi money laundering yang diwujudkan dalam lingkup the Forty FATF Recommendations. FATF telah setuju untuk mengimplementasikan dan di mana semua negara-negara dianjurkan untuk mengadopsinya. Rekomendasi ini pertama kali disusun tahun 1990 dan dalam tahun 1996 dilakukan perbaikan. Forty Recommendations ini bertitik tolak dari kerangka dasar dalam upaya mencegah pencucian uang dan dimaksudkan dapat diterapkan secara universal, meliputi sistem peradilan pidana dan penegakan hukum (law enforcement) sistem keuangan dan peraturannya, dan kerjasama internasional.

Dalam Rekomendasi ke-1 dinyatakan bahwa masing-masing negara seharusnya segera mengambil langkah untuk meratifikasi dan mengimplementasikan secara penuh the United Nations Convention against lilicit Traffic in Narcotic Drugs and Psychotropic Substances, 1988. Sehubungan dengan itu, Indonesia telah meratifikasi convensi tersebut dengan Undangundang No. 7 Tahun 1997 (Lembaran Negara Tahun 1997 Nomor 17). Dengan telah diratifikasinya Konvensi PBB itu, berarti tindak pidana pencucian uang dapat menjadi tindak pidana internasional, khususnya yang berkaitan dengan Illicit Traffic in Narcotic Drugs and Psychotropic Substances.

Namun, perkembangan money laundering tidak hanya terbatas dari hasil Iliicit Traffic in Narcotic Drugs and Psychotropic Substances, tetapi juga meliputi hasil dari kejahatan terorganisir lainnya sebagaimana telah dikemukakan di atas. Pasal 2 Undangundang No. 15 Tahun 2002, pada intinya menentukan bahwa hasil kejahatan yang termasuk dalam lingkup dan diancam dengan pidana berdasarkan Undang-undang ini adalah kejahatan-kejahatan yang meliputi: korupsi; penyuapan; penyelundupan barang; penyelundupan tenaga kerja; penyelundupan imigran; perbankan; narkotika; psikotropika; perdagangan budak, wanita dan anak; perdagangan senjata gelap; penculikan; terorisme; pencurian; penggelapan; penipuan. Cakupan demikian menunjukkan, bahwa kejahatan yang berkaitan dengan pencucian uang merupakan salah satu bentuk dari kejahatan ekonomi dalam arti luas yang meliputi kejahatan di bidang perdagangan, di bidang perbankan, di bidang investasi, korupsi, dan kejahatan-kejahatan di bidang ekonomi lainnya yang termasuk dalam lingkup kejahatan terorganisir. Menurut Muladi, ${ }^{14}$ dalam struktur kejahatan transnasional yang terorganisir, 
money laundering termasuk salah satu kejahatan lanjutan. Namun menurut hemat penulis, bukan salah satu, tapi justru money laundering itu merupakan sarana utama dari berbagai jenis kejahatan yang termasuk dalam organized crime untuk mengaburkan asal-usul perolehan kekayaannya. Misainya, uang hasil korupsi, diupayakan oleh pelakunya untuk disembunyikan sumber perolehannya. Sarana untuk proses penyembunyian itu, baik melalui bank maupun non-bank, atau pun dengan cara-cara lainnya seperti pembelian barangbarang berharga yang sulit dijangkau oleh orang yang berpenghasilan pas-pasan.

Jika di atas telah dikemukakan bahwa pencucian uang termasuk dalam lingkup kejahatan ekonomi, tapi yang menjadi pertanyaan apakah tepat memasukan kejahatan pencucian uang sebagai kejahatan ekonomi terutama dalam kaitannya dengan kejahatan terorganisir? Pertanyaan ini mengemuka, karena seperti yang ditulis oleh Muladi bahwa salah satu karakter dari kejahatan ekonomi adalah tanpa menggunakan kekerasan. Untuk memahami apa yang dimaksud dengan kejahatan ekonomi dan kejahatan terorganisir, maka terlebih dahulu perlu dikemukakan pendapat sebagaimana yang ditulis oleh Edmund $W$. Kitch ${ }^{15}$ bahwa tidak ada definisi kejahatan ekonomi yang diterima secara umum atau berlaku umum. Kejahatan ekonomi barangkali dapat didefinisikan sebagai kejahatan yang dilakukan dengan tujuan atau motif ekonomi. Di samping itu, pengertian dimaksud bisa juga meluas sampai memasuki berbagai jenis kejahatan mulai dari pencurian ringan (misdemeanor larceny) hingga meluas. sampai kepada kejahatan keuangan (financial. crimes), dan mulai dari kejahatan yang dilakukan secara diam-diam hingga kejahatan yang dilakukan secara terang-terangan. Untuk memberikan gambaran mengenai kejahatan ekonomi tersebut, maka Kitch mendefinisikan kejahatan dimaksud sebagai aktifitas krimina! yang menyerupai aktifitas ekonomi normal yang sebenamya, seolah bukan sebagai bisnis kriminal. ${ }^{16} \mathrm{Apa}$ yang telah dikemukakan oleh Kitch tersebut menggambarkan bahwa kejahatan ekonomi itu dillakukan dengan caracara yang halus, dan bahkan sulit pula untuk menentukan apakah sebagai kejahatan atau bukan, karena samar dengan kegiatan bisnis normal atau bisnis yang sebenarnya. Kaitannya dengan pencucian uang, di mana jenis kejahatan ini apabila dilihat sepintas pada dasarnya merupakan urusan keperdataan seseorang yang menyimpan uang di bank atau menanamkan uangnya di suatu perusahaan atau di bidang-bisnis lainnya atau bahkan di lembaga pendidikan (?), sehingga sulit pula (dalam arti awam) melabelkan sebagai kejahatan. Gambaran yang demikian ini diakui oleh Muladi, ${ }^{17}$ karena mengingat kejahatan ekonomi berkembang sesuai dengan

"Muladi, "Kemungkinan Kriminalisasi Money Laundering di Indonesia," Penataran Nasional Hukum Pidana dan Kriminologi, Hotel Siranda, Semarang, 3-15 Desember 1995, him. 6.

${ }^{15}$ Edmund W. Kitch, "Economic Crime", Dalam Sanford H. Kadish (ED), Encyclopedia of Crime and Justice, Volume 2, The Free Press, New York, (1983), hlm. 671.

${ }^{18} \mathrm{Edmund} W$. Kitch, Ibid. Economic crime is defined as criminal activity with significant similarities to the economic activity of nomal, noncriminal business. 
perkembangan teknologi, ekonomi dan sosial suatu masyarakat. Di samping itu, persoalanpersoalan ekonomi merupakan bagian dari kehidupan antarbangsa dalam rangka globalisasi ekonomi. Hubungan-hubungan ekonomi antarbangsa menjadi bersifat interdepedensi dan melewati batas-batas nasional. Menurut Muladi, ${ }^{18}$ kejahatan ekonomi lebih menampakkan dirinya sebagai kejahatan di lingkungan bisnis, yakni bilamana pengetahuan khusus tentang bisnis diperlukan untuk menilai kasus yang terjadi. Atas dasar konstruksi yang demikian, maka yang dimaksud dengan kejahatan ekonomi, adalah setiap perbuatan yang dilakukan oleh orang dan atau badan hukum, tanpa menggunakan kekerasan, bersifat melawan hukum, yang hakikatnya mengandung unsur-unsur penipuan, memberikan gambaran salah, penggelapan, manipulasi, melanggar kepercayaan, akalakalan atau pengelakan peraturan.

Menurut Kitch, ${ }^{19}$ terdapat dua kelompok utama dalam upaya memahami kejahatan ekonomi ini. Pertama, adalah kejahatan yang dilakukan oleh pengusaha seperti menambah kegiatan bisnis mereka yang sudah ditentukan. Sebagai contoh, melakukan penggelapan, melanggar peraturan untuk kepentingan usaha mereka, atau penghindaran pembayaran pajak. Bentuk kejahatan ekonomi seperti ini menurut Kitch sering disebut dengan white-collar crime. Kemudian, kelompok kedua dari kejahatan ekonomi ini adalah persediaan barang dan jasa secara illegal atau persediaan barang dan jasa dengan cara illegal. Persediaan barang dan jasa secara illegal tersebut, membutuhkan kesesuaian dengan kegiatan ekonomi yang dilakukan secara normal, tetapi semua kegiatan tersebut dilakukan dalam lingkup kejahatan. Bentuk kejahatan ekonomi ini sering disebut dengan kejahatan terorganisir (organized crime) karena dalam kejahatan tersebut membutuhkan koordinasi ekonomi yang bertentangan dengan hukum.

Contoh yang dikemukakan oleh Kitch di atas, di Indonesia sebenarnya tidak luput dari praktek semacam itu. RCTI dalam program SILET pemah menayangkan kehidupan dan gemerlapnya kehidupan di ibu kota Jakarta, termasuk bisnis seks di hotel plus-plus yang sengaja dibangun untuk menyediakan bagai mereka yang ingin transaksi asmara di hotel tersebut. Kegiatan bisnis semacam itu, merupakan ciri atau karakter dari kejahatan terorganisir, karena sejak semula dibangunnya hotel dimaksud bukan ditujukan untuk untuk usaha hotel yang sebenarnya, akan tetapi memang dirancang kepada hal-hal yang bertentangan dengan norma-norma hukum, agama atau pun sosial, sehingga orang hanya melakukan pencelaan sebagai usaha haram. Sedangkan norma hukum, apakah usahausaha semacam itu telah diatur dalam hukum pidana, sehingga dicela oleh hukum pidana sebagai suatu kejahatan dan kepada pelakunya dapat dipertanggungjawabkan berdasarkan

\footnotetext{
17Muladi, "Konsep Indonesia tentang Tindak Pidana di Bidang Perekonomian", Dalam Muladi dan Barda Nawawi Arief (ED), Bunga Rampai Hukum Pidana (Bandung: Penerbit Alumni, 1992), hal. 12.

${ }^{18}$ Muladi, Konsep Indonesia ..... op.cit, hlm. 19.

${ }^{19}$ Edmund W. Kitch, "Economic Crime", Dalam Sanford H. Kadish (ED), Encyclopedia of Crime and Justice, Volume 2, The Free Press, New York, (1983), hlm. 671.
} 
undang-undang yang telah mengaturnya.

Untuk memahami apa yang dimaksud dengan kejahatan terorganisir tersebut, maka yang perlu dikemukakan terlebih dahulu adalah istilah dari kejahatan terorganisir (organized crime) itu sendiri. Istilah organized crime telah lama menjadi sumber kontroversi dan perdebatan, hal itu terjadi mungkin karena perbedaan dalam cara pendekatan terhadap berbagai permasalahan yang dihadapi. Suatu konsensus utama telah muncul meskipun atas beberapa syarat yang harus dipenuhi sebelum istilah tersebut mungkin dianggap dapat diterapkan. Akan tetapi dalam Article 2 ayat 1 Proposal dan Contributions Received from Govemments, dinyatakan ${ }^{20}$ bahwa organized crime berarti kegiatan-kegiatan yang bertujuan (melakukan perbuatan) dalam rangka (dalam kaitannya dengan) sebuah organisasi kejahatan. Selanjutnya dalam ayat (2) dinyatakan: Sebuah organisasi kejahatan (a criminal organization) berarti suatu kelompok (tiga atau lebih) orang dengan hubungan hirarki atau hubungan personal yang dapat bertahan lama untuk tujuan memperkaya diri atau pengawasan wilayahwilayah atau pasar-pasar, baik di dalam maupun di luar negeri (intemal orforeign) dengan cara melawan hukum seperti kekerasan, ancaman atau korupsi, kedua dalam memajukan aktivitas kejahatan itu supaya masuk ke dalam ekonomi yang sah.

Para pengikut organisasi kejahatan dianggap sebagai kelompok orang untuk tujuan melakukan kegiatan kejahatan. Mereka biasanya menggunakan perusahaan untuk melakukan kejahatan, yakni menyediakan barang-barang gelap dan jasa, atau barang: barang legal yang telah diperoleh cara-cara yang haram, yaitu seperti mencuri atau perbuatan-perbuatan curang lainnya. Kejahatan terorganisir (organized crime) menampakkan yang sebenarnya dalam setiap perluasan ruang gerak pasar yang sah masuk menjadi bidang yang biasanya dilarang. Aktivitas kelompok kejahatan terorganisir memerlukan tingkat kerjasama yang baik dan organisasi untuk menyediakan barang-barang haram dan jasa. Seperti dalam melakukan bisnis, di mana bisnis kejahatan memerlukan ketrampilan sebagai pengusaha, dan kemampuan untuk koordinasi. Di samping melakukan kekerasan dan kecurangan adalah untuk memfasilitasi dalam mengadakan kegiatan-kegiatan lainnya.

Penyebutan kelompok kejahatan terorganisir tersebut, dalam Annex I UN Convention against Transnational Organized Crime, ${ }_{1}^{21}$ telah diberi batasan sebagaimana tercantum dalam Article 2 tentang Use of tems. Di mana dalam huruf (a) dinyatakan kelompok kejahatan terorganisir berarti sebuah kelompok yang terstruktur (structured group) ${ }^{22}$ dari tiga atau lebih orang, keberadaannya untuk periode waktu tertentu dan bertindak bersama-sama (in concert)

${ }^{20}$ General Assembly, AAC.254/5 19 December 1998.

${ }^{21}$ General Assembly, Report of the Ad Hoc Committee on the Elaboration of a Convention against Transnational Organized Crime on the work of its first to eleventh sessions, 2 November 2000, A/55/383.

${ }^{22}$ Structured group shall mean a group that is not randomly formed for the immediate commission of an offence and that does not need to have formally defined roles for its members, continuity of its membership or a developed structure, Article 2 (c) UN Convention against Transnational Organized Crime. 
dengan tujuan melakukan satu atau lebih kejahatan-kejahatan yang berat (serious crime) ${ }^{23}$ atau melakukan pelanggaran sebagaimana yang diatur dalam Convensi:ini, dengan maksud untuk mendapatkan baik langsung atau tak langsung keuangan atau keuntungan material lainnya.

Mengingat operasi kegiatan kejahatan terorganisir tidak hanya dalam skala lokal nasional, tetapi juga dunia internasional, sehingga penyebutannya pun menjadi organisasi kejahatan transnasional (transnational criminal organization). Penggunaan instilah transnational untuk criminal organization tersebut pada umumnya digunakan untuk menunjuk kepada pergerakan informasi, uang, barang, orang, barang berwujud dan tak berwujud - lainnya yang melintasi batas-batas negara.

Sehubungan dengan uraian di atas, Mardjono Reksodiputro ${ }^{24}$ menulis bahwa kejahatan terorganisir mengacu pada organisasi rahasia (seperti mafia) dan mempunyai jaringan yang luas. Luasnya jaringan itu, hingga sampai pula kepada organisasi-organisasi bisnis yang sah. Oleh karena itu, keliru untuk menggambarkan kejahatan terorganisir sebagai organisasi yang hanya bekerja dengan tukang-tukang pukul atau bergerak dalam kegiatan yang tidak boleh dilihat oleh penegak hukum.
Di Belanda sebagaimana yang ditulis oleh Dieter Schaffmeister ${ }^{25}$ bahwa mengenai kejahatan terorganisisr ini telah banyak mendapat perhatian dalam ilmu hukum pidana dan dalam praktek hukum pidana sejak awal 1980-an. Perhatian utama adalah berkaitan dengan perdagangan obat dan perdagangan menguntungkan lainnya secara ilegal atas benda-benda langka seperti hewan dan tumbuh-tumbuhan yang dilindungi, benda-benda seni dan mobil-mobil mewah, juga penyelundupan manusia dan perdagangan wanita. Bentuk kejahatan ini dilakukan dengan bantuan badan-badan swasta (private entities) atau kelompokkelompok (gangs) atau jaringan-jaringan (networks), dilakukan secara sistematis oleh kelompok orang dan ciri utamanya adalah perolehan keuntungan secara ilegal dan menggunakan kekerasan hanya untuk tujuan contra-strategies.

Berdasarkan uraian dia atas, maka gambaran tentang karakter dari kejahatan ekonomi merupakan kejahatan yang dilakukan tanpa kekerasan, tentu tidaklah berlaku absolut dalam konteks pencucian uang dan kejahatan terorganisir. Adapun kegiatankegiatan dari organisasi kejahatan ini meliputi berbagai kegiatan gelap dan sulit untuk mengungkapnya secara komprehensif.

\footnotetext{
${ }^{23}$ Serious crime shall mean conduct constituting an offence punishable by a maximum deprivation of liberty of at least four years or a more serious penafty, Article 2 (b) UN Convention against Transnational Organized Crime.

24Mardjono Reksodiputro, "Kejahatan Terorganisasi dan Kejahatan oleh Organisasi (Suatu Tinjauan dari Segi Kriminologi)", Dalam Jumal Polisi Indonesia, Tahun: 2, April 2000-September 2000, hlm. 39.

${ }^{25}$ Dieter Schaffmeister, "Collective Crimes", Disampaikan dalam Seminar mengenai Intemasional Criminal Law and Collective Crimes:Problems and Prospects, Bertempat di Auditorium of the Ministry of Law \& Legislation, Jakarta, 24 Agustus 2000.
} 
Kegiatan organisasi kejahatan tersebut sebagaimana yang dikemukakan dalam World Ministerial Conference on Organized Transnational Crime di Naples, 21-23 Nopember 1994 adalah:

\section{a. The drug trafficking industry}

Untuk memahami apa yang menjadi sumber penghasilan utama bagi kebanyakan organisasi kejahatan internasional, maka kegiatan perdagangan obat terlarang dapat dipahami dengan baik sebagai sebuah industri, dengan tingkat perbedaan produksi dan distribusi pada tingkat partai (borongan) dan eceran. Hal itu juga sangat menguntungkan industri, sebab sebagian besar perdagangan tersebut dibatasi kompetisi di antara perusahaan-perusahaan dan sedikit ancaman dari produk-produk pengganti, karena baik supplier bahan mentah maupun konsumen produk akhir mempunyai kekuatan yang terbatas. Uang yang diperoleh dari industri perdagangan gelap obat terlarang sebagian besar masuk kepada organisasi-organisasi perdagangan gelap tersebut, tapi petani-petani yang sebenamya menanam cocain dan opium itu mendapatkan imbalan yang sangat rendah, walaupun hal itu pada umumnya lebih baik daripada keuntungan yang diperoleh dari penanaman komoditi lainnya. Munculnya industri perdagangan gelap obat terlarang sebagai sebuah multi-billion-dollar setiap tahun, kegiatan tersebut telah memberikan dorongan yang besar bagi pengembangan organisasi kejahatan transnasional dan juga telah menimbulkan adanya money laundering as a high-profile activity. Kegiatan-kegiatan tersebut juga menandakan peningkatan pertumbuhan keterkaitan dengan jenis peredaran gelap lainnya, khususnya senjata.

\section{b. Smuggling of illegal migrants}

Meskipun angka pertumbuhan penduduk dunia lambat, tetapi jumlah penduduk dunia tetap meningkat, dan berdasarkan laporan Badan Sensus PBB tahun 1998 bahwa 96\% pendudukan dunia meningkat dan terjadi di Afrika, Asia dan Amerika Latin. Bersamaan. dengan faktor-faktor lain, peningkatan pertumbuhan pendudukan di negarta-negara berkembang (developing countries) menimbulkan peningkatan gelombang (permintaan) migrasi. Bagaimanapun juga dalam tahun-tahun ini ada upaya-upaya untuk mengurangi kesempatan secara legal berimigrasi ke banyak Negara. Meningkatnya keinginan untuk berimigrasi, baik karena alasan kebutuhan ekonomi maupun alasanalasan kemanusiaan telah dipersulit dengan adanya pembatasan secara hukum berimigrasi ke banyak Negara di dunia. Akan tetapi, akibatnya banyak orang ingin mencari cara di luar jalur hukum. Keadaan demikian, tentunya memberikan peluang bagi kelompok-kelompok tertentu untuk memperoleh keuntungan dengan menyediakan jasa bagi mereka yang akan berimigrasi secara gelap, atau penyelundupan orang. Peluang yang menguntungkan bagi yang mampu menyediakan jasa penyelundupan orang secara gelap tersebut memang sesuautu yang sangat menarik, tidak hanya penjahat-penjaha' oputunis lokal, tetapi juga jaringan penjaha terorganisir transnasional. Peningkatan kejahatar yang melibatkan kelompok kejahatar terorganisir dalam penyelundupan orang dar perdagangan gelap telah menarik perhatiar dunia internasional. ${ }^{26}$ 
Adapun cakupan dari jenis kejahatan ini adalah pertama, yang berkaitan dengan isu migran ilegal, berdasarkan perkiraan dari sebuah laporan menyatakan bahwa organisasi kejahatan tersebut sekarang mencoba menyelundupkan sebanyak mungkin orang setiap tahun. Perbuatan itu tidak hanya mengancam unsur dasar kedaulatan nasional, tetapi juga menempatkan para imigran itu sendiri ke dalam bahaya yang mengkhawatirkan.

Mereka itu mempunyai tingkat kerentanan yang sangat tinggi dan wanita khususnya sering dipaksa ke dalam perbudakan seksual (sexual slavery). Bahkan mereka yang tiba di tempat tujuan sering berhutang kepada penyelundup dan dipaksa untuk melakukan kegiatan kriminal guna membayar hutang. Permasalahan ini telah menjadi perhatian besar di negara-negara Barat, sebagian besar dalam kaitannya dengan imigran Cina, dan itu tidak hanya masalah Amerika Serikat atau Eropah, serta tidak hanya terbatas terhadap imigran Cina, tetapi juga imigran dari negaranegara lainnya.

Sehubungan perkembangan jenis kejahatan tersebut, maka Menteri Koordinator Politik dan Keamanan (Menkopolkam), Susilo Bambang Yudhoyono pernah mengatakan bahwa sikap pemerintah Indonesia terhadap sindikat penyelundupan imigran asing yang menggunakan Indoriesia sebagai tempat transit ke negara ketiga, pemerintah Indonesia bertekad akan membongkar habis sindikat itu.
Pernyataan Menkopolkam tersebut terkait dengan ditangkapnya Abu Quassey alias Abu Kaiz alias Centin Kaya Nagu, pria asal Turki berkewarganegaraan Mesir, yang diduga sebagai otak penyelundupan manusia dari Timur Tengah ke Australia melalui Indonesia. Penangkapan itu sendiri berkaitan dengan peristiwa tenggelamnya kapal yang mengangkut 418 imigran gelap asal Irak, Iran, Palestina, Afghanistan, dan Aljazair di perairan Samudra Hindia pada tanggal 21 Oktober 2001.27.

Permasalahan imigran gelap ini, jelas tidak dapat dibiarkan begitu saja, karena akan membebani pemerintah baik dari segi finansial seperti biaya kesehatan, makanan, penampungan dan tranfortasi, maupun dalam hubungannya dengan negara lain. Dalam kasus ini adalah dengan Australia.

Australia dalam menyikapi imigran gelap ini, sekarang menyetujui pendekatan menyeluruh untuk memecahkan persoalan penyelundupan orang. Untuk itu, dilakukan kerjasama yang luas antara sejumlah lembaga-lembaga untuk memainkan peranan dalam bidang penegakan hukum, sebagai contoh kejasama antara Australian Federal Police (AFP) dan Department of Immigration and Multicultural Affairs (DIMA) People Smuggling Strike Team. Mengenai data terhadap orang yang ditemukan telah diselundupkan ke Australia disediakan oleh DIMA termasuk statistic pendatang illegal yang ditangkap di wilayah udara Australia dan perbatasan laut. ${ }^{28}$

${ }^{25}$ Australian Institute of Criminology, Organized Crime and People Smuggling/Trafficking to Australia, No. 208, hlm. 1.http:/hwww.aic.gov.au

${ }^{27}$ GATRA.com, 09-11-2001, Memburu Sindikat Penyelundup Manusua, Cover Gatra: No. 51 $\mathrm{Nl}, 10$ November 2001. 


\section{c. Arms trafficking}

Perbedaan antara suplai persenjataan yang legal dan haram tidak begitu jelas. Penyediaan bahan kimia dan penyediaan yang diperlukan untuk mengembangkan senjata nuklir, sering kali dihubungkan dengan kehendak pembeli. Dalam soal yang sama, pembeli itu mungkin dari sebuah negara (yang dicap sebagai negara teroris), sehingga masyarakat internasional berupaya untuk mengucilkannya, atau dengan kata lain pembeli senjata itu dapat juga dilakukan oleh sebuah kelompok etnik yang berusaha mengatasi adanya embargo senjata.

Akan tetapi, siapapun pembeli itu, bagaimanapun juga berkaitan dengan peredaran senjata di pasaran gelap.

\section{d. Trafficking in nuclear material}

Perdagangan bahan-bahan nuklir merupakan masalah utama dalam kaitannya dengan bekas negara Uni Soviet, kemungkinan bahwa bahan senjata nuklir tersebut disalurkan kepada kelompok teroris yang mencoba untuk memperoleh beberapa jenis senjata nuklir strategis pada dasamya menupakan persoalan penting yang berkaitan dengan masyarakat global. Perdagangan yang demikian jelas mempunyai potensi yang tinggi bagi timbulnya korban, yaitu seperti kerusakan lingkungan sebagai akibat dari penanganan bahan-bahan tersebut secara tidak benar.

\section{e. Transnational criminal organization and terrorism}

Mengingat kegiatan organisasi kejahatàn transnasional, baik dengan menggunakä taktik teror maupun hubungannya dengann teroris dan gerilya organisasi merupakan tema yang selalu berulang. Jika organisasi kejahatän sering melakukan teror dan membangun aliansi dengan teroris, namun demikian hâl itu jelas bahwa kedua jenis organisasi kejahatan tersebut mempunyai tujuan yang sangat berbeda. Organisasi kejahatan transnasional menggunakan teror hanya untük menentukan lingkungan yang lebih cocok bagi perusahaan mereka untuk melakukan kejahatan. Mereka umumnya menyadari bekerja dalam sistem tersebut selama hal itư dapat diatasi sejauh mereka mempunyải tujuan politik yang ditujukan terhadap kebijakan penegakan hukum tertentu yang lebih menggambarkan bagian dari upaya untuk menghilangkan adanya struktur kekuasaan. Sedangkan kelompok teroris adalah sebaliknya, yaitu mencapai tujuan politik dan sering ditujukan untuk menjatuhkan status quo baik pada tingkat nasional maupun internasional. Meskipun kelompok teroriș melakukan kejahatan seperti perdagangan obat dan senjata, hal itu biasanya dilakukan untuk menyediakan dana yang memungkinkan bekerja lebih efektif dalam melaksanakan agenda politik mereka.

\section{f. Trafficking in women and children}

Prostitusi sudah lama menjadi unsur

\footnotetext{
${ }^{28}$ Australian Institute of Criminology, Organized Crime and People Smuggling/Trafficking to Australia, No. 208, him. 3. http:/hww. aic.gov.au
} 
utama dalam kegiatan organisasi kejahatan pada tingkat nasional, atau pun juga pada dimenș internasional. Organisasi kejahatan Triads dan Yakuza khususnya aktif di bidang ini dan menjadikan wanita sebagai budak dalam industri seks wisata (tourist sex industry) di Pilipina, Korea Selatan dan Thailand. Jenis perdagangan gelap ini menjadikan suguhan wanita sebagai komuditi yang mempunyai nilai pasar. Bekerja seks merupakan bagian besar dalam dunia ekonomi di mana. wanita dan anak-anak dipandang sebagai barang yang menyenangkan.

Sesuai dengan isu tersebut, maka dalam kaitan ini patut dikemukakan sebuah kejadian yang menimpa Tenaga Kerja Indonesia (TKI) beberapa waktu lalu yang diusir dari Malaysia dan kemudian ditampung di Nunukan, Kalimantan Timur. Di mana mereka yang terlibat dalam urusan TKI sengaja memeras TKI demi dollar. ${ }^{23}$

Agen tenaga keja di Sabah, Malaysia dan mitranya Perusahaan Pengerah Jasa Tenaga Kerja Indonesia (PJTKI) di Nunukan, Kalimantan Timur sengaja menjadi penjual TKI, termasuk dalam pengurusan pemutihan paspor setelah dideportasi dari Malaysia akhir bulan Juli 2002. Dengan demikian, merekalah sebenarnya membuat para TKI tersebut menderita. Untuk pengurusan paspor di Nunukan para TKI menyetor uang 1.400 ringgit atau sekitar Rp 3,2 juta kepada agen TKI, kemudian biaya tersebut diberikan kepada mitranya sebesar 1.200 ringgit sebagai biaya untuk penyelesaian dokumen, transportasi dan biaya-biaya lainnya selama di Nunukan. Padahal biaya pengurusan paspor di Kantor Imigrasi Nunukan hanya Rp 115.000 per orang. Majikan TKI yang sangat membutuhkan tanaganya menyerahkan uang kepada agen sebesar 1.400 ringgit per orang. Di samping itu, biaya yang berjumlah 1.200 ringgit yang digunakan untuk pengurusan-paspor dan transportasi tersebut pada dasarnya merupakan piutang yang harus dikembalikan dengan cara mencicil setiap bulan berkisar antara Rp 250.000 hingga Rp 300.000 dari gaji yang mereka terima kurang lebih $R p$ 480.000. Pinjaman itu baru lunas sekitar 3 hingga 4 tahun kemudian dengan jaminan paspor, tidak termasuk biaya pengamanan selama di Sabah, Malayșia yang jumlahnya mencapai Rp 1.000.000.

Perihal perdagangan manusia ini tidak hanya melalui jalur PJTKI, tetapi juga sebagaimana yang diberitakan oleh Media Indonesia Online ${ }^{30}$ bahwa polisi berhasil membongkar sindikat penjual ABG (Anak Baru Gede) untuk dijadikan WTS (wanita tuna susila) dan menangkap tiga germo di lokalissași Teleju Pekanbaru pada hari Jum'at 28 Pebruari 2003. Tiga ABG yang berasal dari Cianjur Jawa Barat itu, semula dijanjikan akan bekerja di Jakarta, tapi kenyataannya dijadikan WTS dan dijual dengan harga dua juta rupiah per orang. Polisi berhasil membongkar sindikat penjualan ABG tersebut adalah berdasarkan informasi

${ }^{29}$ Media Indonesia, Manakala Oknum Imigrasi, PJTKI dan Agen Tertibat Jual-beli TKI, http://uwww.mediaindoensia.com, diakses tanggal 25 September 2002.

${ }^{30}$ Media Indonesia Online, Sindikat Penjual WTS ABG Dibongkar Polisi, http:/hwww.media-indonesia.com, diakses tanggal 02 Maret 2003. 
masyarakat dan laporan pers.

Adanya sindikat penjualan $A B G$ tersebut menunjukkan bahwa kejahatan terorganisir itu sudah merambah ke Indonesia, demikian juga halnya dengan smuggling of illegal migrants sebagaimana telah dikemukakan di atas, dan ini merupakan tantangan bagi Indonesia untuk menanggulanginya

\section{g: Trafficking in body parts}

Satu alasan bagi timbulnya kecurigaan terhadap penculikan berkaitan derigan adanya penculikan anak-anak yang akan dibunuh untuk diambil bagian-bagian tubuhnya. Meskipun hal itu sedikit fakta yang menunjukkan bahwa penculikan tersebut dilakukan untuk maksud tersebut, akan tetapi adalah jelas bahwa itu menguntungkan pasar gelap dalam perdagangan bagian-bagian tubuh manusia, khususnya di Argentina dan Federasi Rusia. Di Argentina sebagai contoh, sudah merupakan contoh serius sehubungan dengan adanya penyalahgunaan pencangkokan (transplant abuses), bahkan sering pemindahan comea pasien yang telah dinyatakan otaknya tidak berfungsi setelah dilakukan scan otak.

Permasalahan semacam itu lebih hebat lagi yang terjadi di Federasi Rusia, di mana ditemukan sebanyak 4.000 tubuh tak dikenal di Moskow. Satu laporan investigasi telah menemukan satu perusahaan yang telah mengumpulkan 700 organ tubuh utama, ginjal, hati dan paru-paru. Lebih dari 1.400 bagian-bagian hati, 18.000 organ hidup, 2.000 mata dan lebih 3.000 pasang biji kemaluan. Lagi pula, penyelidik forensik Moskow menemukan bahwa kegiatan tersebut benarbenar di bawah kendali kejahatan terorganisir dalam melakukan penculikan anak-anak dan orang dewasa, menggunakan organ mereka untuk pencangkokan dan percobaan di bidang kedokteran. Di samping itu, transpalansi organ merupakan bisnis yang sangat menguntungkan di Rusia dan itu akan terus berlanjut.

\section{h. Theft and smuggling of vehicles}

Persoalan signifikans lainnya adalah pencurian dan penyelundupan kendaraan bermotor. Modus yang dilakukan berbeda dengan perdagangan obat, mobil-mobil dicuri dari negara-negara industri maju, dikirim ke para elit di negara-negara sedang berkembang atau negara-negara dalam transisi. Ini telah menjadi persoalan besar di wilayah Hong Kong, di mana mobil-mobil mewah dicuri dan dengan cepat dikirim ke Cina dengan menggunakan kapal yang berkepatan sangat tinggi.

Jenis-jenis kejahatan yang dikemukakan di atas tadi, salah satu dari aktivitas utamanya adalah mencari keuntungan, selanjutnya hasil yang diperoleh dari perdagangan gelap obatobat terlarang atau hasil-hasil lainnya yang diperoleh secara ilegal dimasukan ke dalam sistem keuangan global, sehingga seolah menjadi hasil yang diperoleh dari usaha yang sah.

\section{Simpulan}

Pencucian uang sebagai salah satu jenis kejahatan dari kejahatan terorganisir sẹbagaimana sudah dikemukakan di atas, pada dasarnya merupakan kejahatan lanjutan dari jenis kejahatan terorganisir. Untuk itu, dalam upaya menanggulangi atau memerangi kejahatan terorganir, maka caranya adalah mencegah lembaga-lembaga keuangan, baik bank maupun non-bank digunakan sebagai sarana untuk membersihkan kekayaan yang 
diperoleh secara tidak bersih itu dengan menggunakan sarana hukum pidana. Mengenai hal ini telah melakukannya dengan mengkriminalisasikan kejahatan pencucian uang sebagai suatu kejahatan yang dilarang dan diancam dengan pidana bagi barangsiapa yang melakukannya sesuai dengan ketentuan Undang-undang No. 15 Tahun 2002.

Meskipun telah memiliki Undang-undang dimaksud, bukan berarti pekerjaan selesai. Undang-undang ini masih perlu dilakukan peninjauan ulang, mengingat ada rumusan pasalnya yang tidak sesuai dengan semangat dibuatnya Undang-undang tersebut.

\section{Daftar Pustaka}

Alper, Benedict S. 1973, Changing Concept of Crime and Criminal Policy, Dalam Resource Material Series No. 6, UNAPEI, Fuchu, Tokyo, Japan, Oktober 1973. Crime is the oldest social problem on which there has been intemational concem and action, beginning in 1825, and recorded in more than 80 intemational conferences held on this subject between then and 1970. 1973.

Ambassador Wendy Chamberlin, Principal Deputy Assistant Scretary, Bureau for International Narcotics and Law Enforcement Affairs, U.S. Department of State, in Economic Perspectives. The Fight Against Money Laundering.

Hoefnagels, G. Peter. The Other Side of Criminology, An Inversion of the Concept of Crime.1972.

Kitch, Edmund W., 1983. "Economic Crime", Dalam Sanford H. Kadish (ED), Encyclopedia of Crime and Justice, Volume
2. New York: The Free Press.

Muladi. "Konsep Indonesia tentang Tindak Pidana di Bidang Perekonomian". Dalam Muladi dan Barda Nawawi Arief (ED), Bunga Rampai Hukum Pidana, Bandung: Alumni, 1992.

- "Kemungkinan Kriminalisasi Money Laundering di Indonesia". Penataran Nasional Hukum Pidana dan Kriminologi, Hotel Siranda, Semarang, 3-15 Desember 1995.

Sudarto. Hukum dan Hukum Pidana. Bandung: Alumni, 1983.

Sahetapy, J.E: Teori Kriminologi Suatu Pengantar. Bandung: Citra Aditya Bakti, 1992.

Schaffmeister, Dieter:. "Collective Crimes". Disampaikan dalam Seminar mengenai Intemasional Criminal Law and Collective Crimes: Problems and Prospects, Bertempat di Auditorium of the Ministry of Law \& Legislation, Jakarta, 24 Agustus 2000.

Australian Institute of Criminology, Organized Crime and People Smuggling/Trafficking to Australia, No. 208, hal. 3. http:ll www.aic.gov.au

GATRA.com, 09-11-2001. Memburu Sindikat Penyelundup Manusua. Cover Gatra: No. 51NII, 10 November 2001.

Media Indonesia Online. Sindikat Penjual WTS ABG Dibongkar Polisi. http:// www.media-indonesia.com, diakses tanggal 02 Maret 2003.

Reksodiputro, Mardjono. “Kejahatan Terorganisasi dan Kejahatan oleh 
Organisasi (Suatu Tinjauan dari Segi Kriminologi)". Dalam Jurnal Polisi Indonesia. Tahun: 2, April 2000 - September 2000.

\section{Instrumen Internasional}

United Nations Economic and Social Council, Strengthening Existing International Cooperation in Crime Prevention and Criminal Justice, Including Technical Cooperation in Developing Countries, with Special Emphasis on Combating Organized Crime, Commission on Crime Prevention and Criminal Justice, First session, Vienna, 21-30 April 1992.

United Nations, Economic and Social Council, Appropriate Modalities and Guidelines for the Prevention and Control of Organized Transnational Crime at the Regional and Intemational Levels, World Ministerial Conference on. Organized Transnational Crime, Naples, 21-23 November 1994.
United Nations Economic and Social Council Problem and Dangers Posed by Orga. nized Transnational Crime in the Various Regions on the World, World Ministerial Conference on Organized Transnational Crime, Naples, 21-23 November 1994.

General Assembly, Report of the Ad Hoc Committee on the Elaboration of a Convention against Transnational Organized Crime on the work of its first to eleventh sessions, 2 November 2000, A/55/383.

Financial Action Task Force on Money Laundering, Basic Facts about Money Laundering, http://www1.oecd.org/fatf/ MLaundering en.htm, diakses 19/06/ 2002.

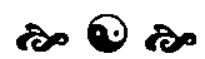

